\title{
Customer's decisiveness about food safety apprehensions of dairy products: A consumer-centric approach
}

\author{
Priyajoy Kar and HR Meena
}

Received: 14 April 2019 / Accepted: 05 July 2019 / Published online: 28 October 2019

(C) Indian Dairy Association (India) 2019

\begin{abstract}
The aim of the present study was to examine the knowledge and attitude related to food safety issues among consumers who had been the major consumers of the food items in the sample area. Interviews of 200 randomly selected consumers representing two districts in northern India were conducted. The study found significant differences among the age groups concerning attitude towards food safety practices. No significant differences in the demographic profile of the respondents about food safety practices were found. These findings indicated increased concerns about food safety knowledge and practices among the consumers. It is recommended that national surveys should be steered, followed with a suitably designed food safety public health campaign, to enhance food safety cognizance.
\end{abstract}

Keywords: Attitude, Cognizance, Food safety, Knowledge

\section{Introduction}

Food safety generally means the intended degree of confidence that food will not cause sickness or harm to the consumer when it is prepared, served and eaten according to its intended use (FAO/WHO, 2003). Food safety is everybody's concern and it is

\footnotetext{
Dairy Extension Division

ICAR-National Dairy Research Institute, Karnal - 132 001, Haryana, India

Priyajoy Kar $(\square)$

Dairy Extension Division

ICAR-National Dairy Research Institute, Karnal - 132 001, Haryana, India

E-mail: karpriyajoy@gmail.com
}

a very important factor in our daily life. Food-borne illness may cause due to the intake of food contaminated by pathogens, toxic chemicals and radioactive materials (Henson \& Traill, 1993).The World Health Organization (WHO) and Food and Agriculture Organization (FAO) states that food is considered safe if there is reasonable certainty that no harm will result from its consumption under expected conditions of use. Ensuring food safety has become an important aspect in the present global scenario of changing food habits and globalization of our food supply. As the food supply chain is becoming more globalized, the need for strengthening our food safety systems has become more evident. Raw contaminated foods, inadequate food preparation techniques and consumption of foods from unsafe sources were the most common factors associated with the different food borne illness (Mederios et al. 2001). Different malpractices in food safety chain have undermined the confidence of the customers. They have major concerns regarding different pesticide usage, expiration dates, safer packaging etc. (Tent, 1999). There are different regulations being imposed by the different governments for competent handling, storage and preparation of food items but seldom the consumers follows it. There is a great need of enlightening the consumers about the perils of indecorous food handling practices. Food safety has been in swelling consideration in the modern days due to the inherent globalization of the food resource which have some predominant confrontational effects. Urbanization, amendments in microbial and other biological systems, and weakening provisions of food and fresh water were the most important factors in question. A much more serious challenge is conceivable, however, in linking with changes resulting directly in the degradation of sanitation which will immediate harm the human health and environment. The need for enriched food safety education is in fact growing in the developed countries through launching different awareness initiatives. People from different ages through their self-reported behaviors will safeguard food safety practices conferring to their requirements. (Bruhn \& Schutz, 1999; Gettings \& Kiernan, 2003; Li-Cohen \& Bruhn, 2002)

The aim of the present study was to measure the attitude of the consumers towards prevailing food safety practices. The different practices staring from the preparation to its handling and its storage were identified and the outlooks of the consumers were 
taken according to that. Knowing the base line assertiveness and belief of the consumers will help in scheming better health educational programs.

\section{Materials and Methods}

\section{Research design}

North Indian states are the leading state in terms of dairy product consumption in the country and they have well developed market for dairy foods, large number of stakeholders of dairy foods. Dairy output as well as per capita dairy products consumption are generally highest in these two states. So, Haryana and Punjab were purposively selected for the present study.

A cross-sectional study of consumer food safety knowledge and practices was conducted from October through December 2016 among two districts in Haryana (Karnal) and Punjab (Ludhiana).An exploratory research design was used in this study to know the consumers opinion about food safety practices. Moreover these two districts were selected according to the presence of one national institute (ICAR-NDRI, Karnal) and one state veterinary university (GADVASU, Ludhiana) who are working in the in the field of dairy production, processing and management.

\section{Instrumentation}

A 40 items written questionnaire was modified version of Vedovato et al. 2014. The questionnaire was tested by 50 experts during August through September 2016, resulting in modifications with the question wording. Finally, ten questions were retained due to expert judgment with proper reliability and validity testing. Reliability was tested through cronbach's alpha which was more than 0.7 . Content validity of the instrument was tested through expert's judgment. The revised questionnaire was divided into four sections:

(1) A demographic section.

(2) Food safety practices.

(3) Food safety behaviors.

(4) Food safety knowledge.

(5) Food handling practices.

Each questionnaire took 20 min to administer. Data were collected on when the customers were most purchasing the food items from the milk parlors in the respective institutes.

\section{Data collection}

The investigator visited each consumer selected and explained the purpose and nature of the study. From each milk parlor 100 consumers were selected who have visited regularly for purchase of milk and milk products. These respondents were selected in response of their Age, Education and any other criteria. Thus, total of 200 respondents were selected for the present investigation. To guarantee anonymity of responses and easy identification of questionnaires by individuals, identity numbers were randomly assigned to each questionnaire. Items in the questionnaire were explained when necessary and administered at one sitting as far as possible.

\section{Statistical analysis}

The SPSS 12.0 statistical package was used for all type of analysis. Mean responses and percentages of responses in each category were calculated and presented in tabular form.

\section{Results and Discussion}

\section{Profile of respondents}

It is of paramount importance to describe the background of the respondents, as the socio-personal and socio-economic traits play an important role in predicting the purchase intention. We have categorized our total number of respondents into three categories according to the Government prescribed norms. Majority of the respondents belongs to young age group (78.00\%) followed by adult age group (18.00\%) and only 4.00 percent of the respondents were in old group. Majority of the respondents belongs to the young group might be due to that most of the time purchasing of the food items are performed by young persons in the family. Majority of the respondents were male $(63.48 \%)$ followed by female respondents $(36.52 \%)$. In case of family size, majority $(86.00 \%)$ of the respondents have medium family size followed by $(11.00 \%)$ low and only 3 percent respondent have large family size. The data presented in table 1 showed that in the young category an equal $(50.00 \%)$ distribution of respondents in the categories of nuclear and joint family. In case of adult respondents majority (54.54\%) were having joint family type, whereas 75.00 percent old category respondents have nuclear family. The table 1 indicated that majority of the respondents in the young category falls into the urban background $(55.13 \%)$ followed $(44.87 \%)$ by rural area.

\section{Sources of Information about the food products}

Knowledge about food items is analyzed through different food items and their different sources of information. Table no 2 indicated that the respondents source of information in category wise distribution. It showed that on an average Majority of Young respondents $(47.76 \%)$ rely on books on cooking as sources for knowledge about food items followed by 46.26 percent on food experts. In case of Adult respondents highest percentage $(48.65 \%)$ of respondents relies on books on cooking followed by food experts (37.11\%).Old respondents regarded their most trusted source of information as food experts $(45.83 \%)$ followed by books 
on cooking (44.91\%). The results of this study are consistent with other studies (Nayga 1996; Lin 1995; and Dosman ,Adamowicz, and Hrudey 2001).

\section{Expenditure Pattern of the Respondents}

As the table 3 indicated that young respondent spending higher amount of money on food followed by house and cloth. In case of Adult respondents they were also spending higher amount of money in food followed by educational purpose of their children. Old respondents were observed their higher amount of money in

Table 1 Descriptive characteristics of the consumers

\begin{tabular}{llllll}
\hline Particulars & Category & & \multicolumn{2}{l}{ Respondents Category } & \\
& & Young $(\mathrm{n}=156)$ & Adult $(\mathrm{n}=36)$ & Old(n=8) & Pooled(n=200) \\
\hline Age(Years) & Anonymous & 78.00 & 18.00 & 4.00 & 51.56 \\
Gender & Male & 63.48 & 63.89 & 75.00 & 67.47 \\
& Female & 36.52 & 36.11 & 25.00 & 32.53 \\
Family Size & Small $(<3)$ & 4.68 & 1.32 & 4.68 & 3.00 \\
& Medium $(3-6)$ & 78.16 & 93.84 & 94.44 & 86.00 \\
& Large $(>6)$ & 17.16 & 4.84 & 0.88 & 11.00 \\
Family Type & Nuclear & 50.00 & 45.46 & 75.00 & 52.27 \\
& Joint & 50.00 & 54.54 & 25.00 & 47.73 \\
Family Background & Rural & 44.87 & 43.46 & 100.00 & 44.17 \\
& Urban & 55.13 & 56.54 & 0.00 & 55.84 \\
\hline
\end{tabular}

Table 2 Sources of Information for knowledge about food items in category wise respondents

\begin{tabular}{|c|c|c|c|c|c|}
\hline \multirow[t]{4}{*}{ Food items } & \multicolumn{5}{|c|}{ Sources of Information for knowledge about food items } \\
\hline & \multirow[t]{3}{*}{ Books on cooking } & \multirow{2}{*}{$\begin{array}{l}\text { Family and } \\
\text { friends }\end{array}$} & \multicolumn{2}{|c|}{ Electronic and Food products } & \multirow{3}{*}{$\begin{array}{c}\text { Food } \\
\text { experts }\end{array}$} \\
\hline & & & social & level & \\
\hline & & \multicolumn{3}{|c|}{ Young category respondents } & \\
\hline Fruits /Vegetable & 48.72 & 8.98 & 19.23 & 10.9 & 50.65 \\
\hline Dairy Products & 69.23 & 29.48 & 24.36 & 30.13 & 61.53 \\
\hline Daily Needs & 40.38 & 32.7 & 17.95 & 29.48 & 44.88 \\
\hline $\begin{array}{l}\text { Animal based } \\
\text { food items }\end{array}$ & 3.84 & 3.21 & 4.49 & 9.62 & 20.52 \\
\hline \multirow[t]{2}{*}{ Average } & 47.76 & 27.03 & 19.55 & 24.57 & 46.26 \\
\hline & & \multicolumn{3}{|c|}{ Adult category respondents } & \\
\hline Chicken/Meat/Fish & 68.19 & 40.91 & 15.91 & 45.45 & 22.72 \\
\hline $\begin{array}{l}\text { Plant based food } \\
\text { items }\end{array}$ & 29.55 & 29.55 & 36.37 & 13.64 & 40.9 \\
\hline $\begin{array}{l}\text { Animal based } \\
\text { food items }\end{array}$ & 4.54 & 2.27 & 6.82 & 6.82 & 27.29 \\
\hline \multirow[t]{2}{*}{ Average } & 48.65 & 24.62 & 19.32 & 23.48 & 37.11 \\
\hline & & \multicolumn{3}{|c|}{ Old category respondents } & \\
\hline Fruits /Vegetable & 63.33 & 50.00 & 37.50 & 12.50 & 75.00 \\
\hline Dairy Products & 68.63 & 12.50 & 37.50 & 12.50 & 62.50 \\
\hline Daily Needs & 50.00 & 12.50 & 37.50 & 0.00 & 25.00 \\
\hline Chicken/Meat/Fish & 25.00 & 37.50 & 12.50 & 62.50 & 50.00 \\
\hline
\end{tabular}


food followed by education as they have to bear their children's educational expenses. Old respondents were spending more money than Young and Adult respondents. Coefficient of variation showing the ample amount of variation among the three groups. Variation of expenditure in different sectors among the three groups are clear from the table number 3.

\section{Attitude of the Consumers towards different food safety Issues}

Empirical research investigated the consumers' attitude towards food safety practices. The three-point Likert scale was used in questionnaire, enabling consumers to express their agreement with certain statements (Marušić, Vranešević, 1997, 240), where 1 represented complete disagreement and 1 was a complete agreement with the statement. Attributes examined were subjective and included healthiness, taste, labeling, quality, price, consumer rights and controlled product origin. These attributes were chosen according to the results of previous research studies, similar as in Vedovato et al. and Radman $(2005,266)$.
Attitudes are generally the mental or emotional entity that inheres in or characterizes a person. It is defined as the settled way of thinking or feeling about something. Respondents are surveyed about their attitudes regarding various issues in food safety. Highest percentages of the consumers $(87.58 \%)$ generally are saying that available information on the food items are not enough to judge its safety. Secondly the respondents were concerned about the sensory evaluation or quality of the food $(87.01 \%)$. About 79.53 percent of the respondents were concerned about the pesticide hazards followed by the diseases and health disorders (79.46\%). Respondents are also concerned about the packaging of the food items $(78.58 \%)$ and the better sustainability and quality of the organic foods (76.02\%).Similar findings are also reported from the research of Miljkovic, Nganje and Ndembe (2008). These results are also stated by Bruhn \& Mason, (2008) who reported that technical and rational aspects of emerging food technologies will lead to consumer acceptance of the food products.

Table 3 Respondents variation in expenditure pattern for various needs

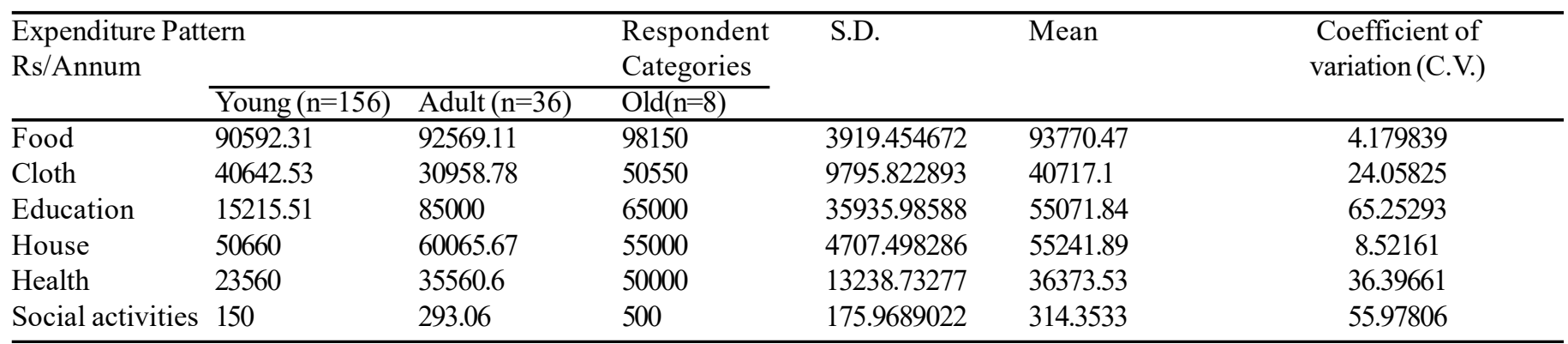

Table 4 Descriptive indicators of research results analysis of consumers' attitude towards food safety practices

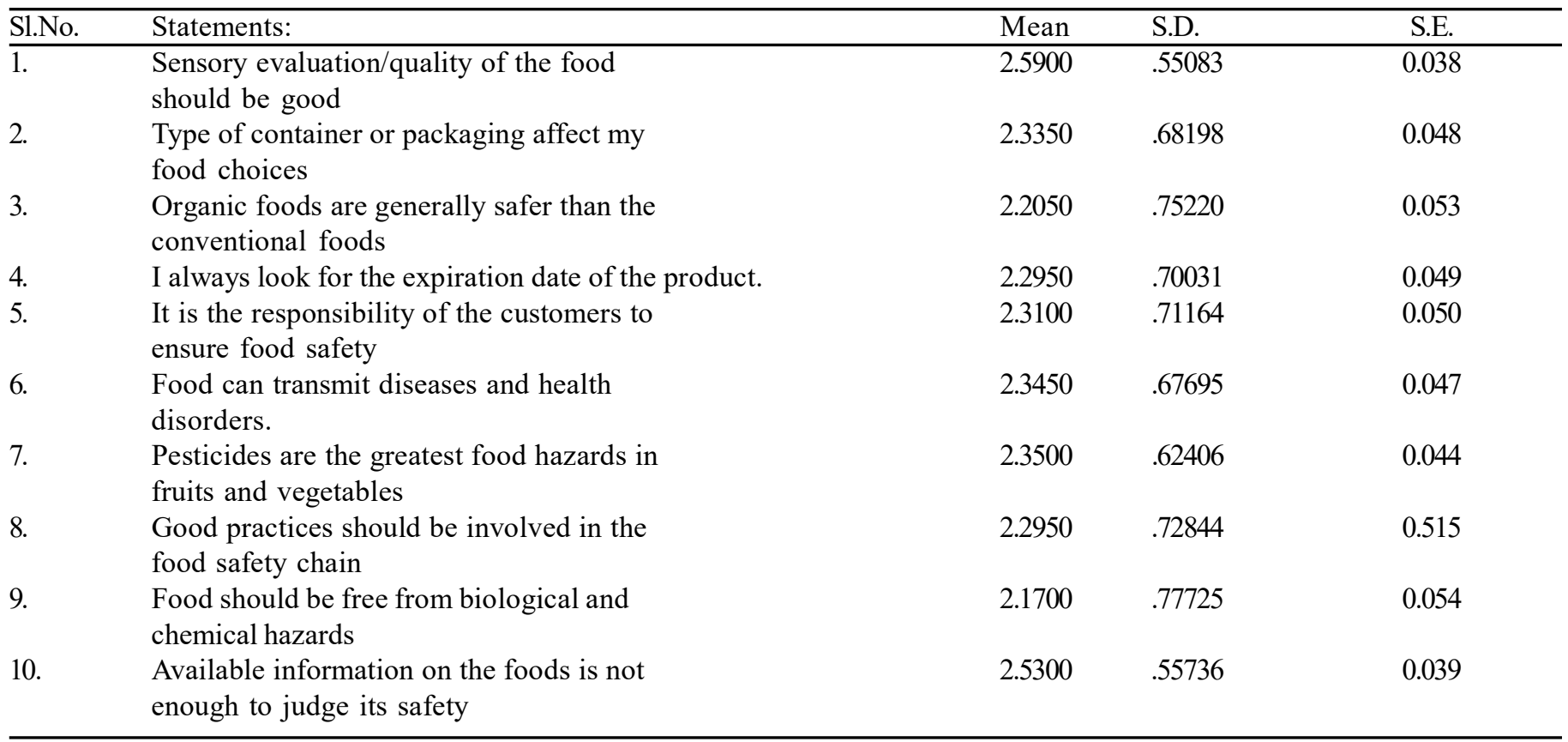


Fig.1 Scree-plot diagram

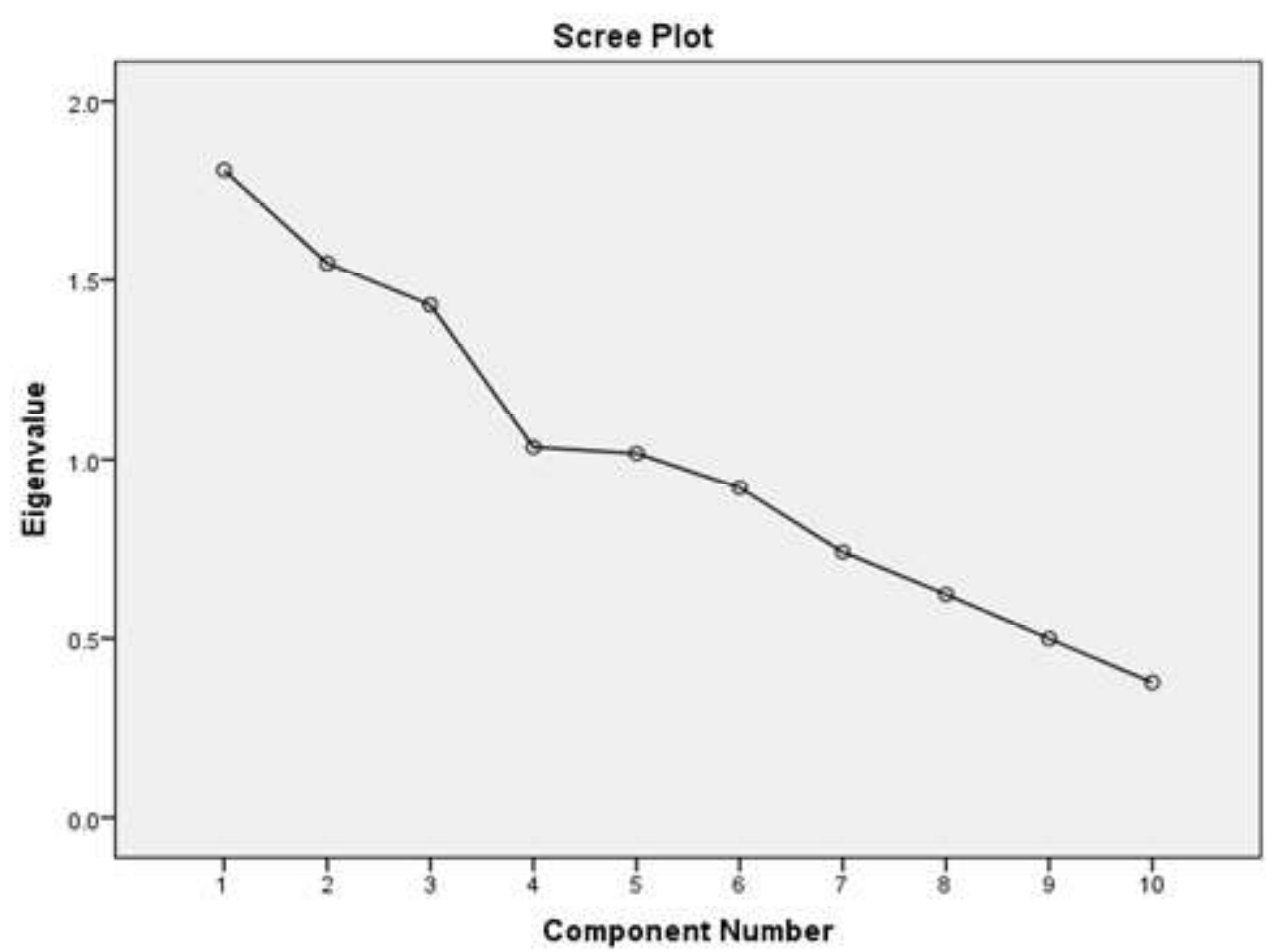

Table 5 Factor matrix (Varimax Rotation)

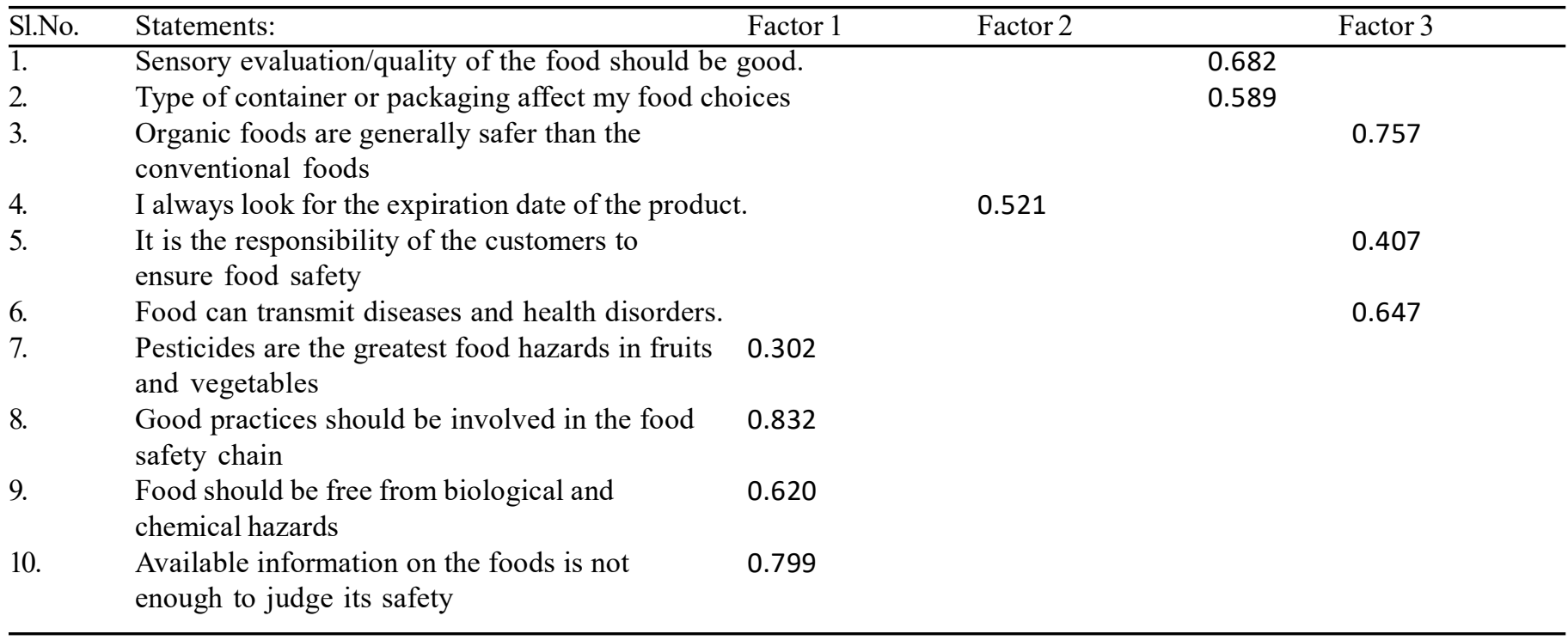

The results of descriptive statistical analysis of variables related to the consumers' attitude towards food safety practices are shown in Table 4

\section{Factor analysis of items connected with the consumers' attitude towards food safety practices:}

Principal component analysis of 10 statements connected with the consumers' attitude towards food safety practices gives a one factor structure, as can be seen from the factor matrix (Table
5). Three factors have been found significantly contributing as the Eigen values were more than 1.0. Using this criterion our data has revealed three factors. All 10 items of the scale can be explained by three factors which explains $58.19 \%$ of Variance.

Table 5 shows factor loadings, correlation between the original variables and the extracted factor. All variables are highly correlated with the extracted factor, which can be defined the factor of attitude towards food safety practices. With the component analysis factor model, later factors extracted contain 
both common and unique variance. The scree test is used to identify the optimum number of factors that can be extracted before the amount of unique variance begins to dominate the common variance structure (Hair, Jr. et al. 2010, 110). Scree plot (Fig. 1) confirms the principal component method and indicates existence of three factors. . The findings of the current study on food safety apprehensions and practices of selected people in Northern India(Haryana and Punjab) corroborate those of Bernudez-Milan, Perez-Escamilla,Damio, Gonzalez, and seguraPerez (2004), Bruhn and Schutz (1999), Clayton, Griffith, and Price (2003), Gettings and Kiernan (2003), Godwin, Coppings, SpellerHenderson, and Pearson (2005), Haapala and Probart (2004), Knight, Jackson, Bain, and Eldemire-Shearer (2003), Mitakakis et al. (2004), and Rimal et al. (2001), Unklesbayet al. (1998).

Internal consistency or reliability of the extracted factor was calculated by Cronbach's alpha and $\alpha=0.71$, which means that the reliability of the factor of attitude of the consumers towards food safety was high.

\section{Conclusions}

Consumers were concerned about the foods they generally bought for their household consumption. Hygiene is considered as an important during the due course of purchasing the food products. Sensory evaluation and Expiration dates of the food items were given due importance by the consumers. There is considerable difference among the different types of the consumers. Responses' regarding different safety issues implies that consumers were knowledgeable, but they lack of awareness and interest on food safety behaviors. Results from this indicates that there is a need for food safety education in the consumers of the respective areas. Different demonstrations and hands on experience should be the part of the safety awareness campaigns to make the consumers conversant with these issues.

The above results have important implications for food safety education programs and government policies. Efforts should be directed towards the improvement of knowledge and food labels presentation so that the consumers can use it in a beneficial way in the coming future. Different food safety measures should be taken up to improve the food safety value chain. Consumers should be well versed with the different bad effects of using pesticides and antibiotics. While the consumers should be made aware about the different labels used in the food products, premier food adulteration agencies like FSSAI, AGMARK, BIS should conduct different awareness programs about the utilization of the food labels among the consumers for better selection of nutritious foods. The Dairy Development plans of different states should encourage and facilitate information among the consumers about the different labels used in the dairy products. In conclusion educational efforts associated with food safety linked with scientific facts should be incorporated in the food supply chain.

\section{Acknowledgements}

The author acknowledges the ICAR-National Dairy Research Institute, Karnal for providing institute fellowship as financial support to carry out the research work.

\section{References}

Bernudez-Milan A, Perez-Escamilla R, Damio G, Gonzalez A, segura-Perez S (2004) Food safety knowledge, attitudes, and behaviours among Rican caretakers living in Hartford, Connecticut. J Food Prot 67: $512-516$

Bruhn CM (2008) Consumer acceptance of food innovations. Innovation Manage Policy Pract 10: 91-5

Bruhn CM, Schutz HG (1999). Consumer food safety knowledge and practices. J Food Saf 19: 73-87

Bulduk S (2003) Gýda ve Personel Hijyeni (Food \& Personnel Hygiene). Detay Yayýncýlýk, Ankara

Clayton DA, Griffith CJ, Price P (2003) An investigation of the factors underlying consumers_implementation of specific food safety practices. Br Food J 105: 434-453

Dosman DM, Adamowicz WL, Hrudey SE (2001) Socioeconomic determinants of health- and food safety-related risk perceptions. Risk Anal 2: 307-317

FAO/WHO (2003) Codex Alimentarius, Basic Text on Food Hygiene. 3rd ed., Italy

Finch C, Daniel E (2005) Food safety knowledge and behaviour of emergency food relief organization workers: effects of food safety intervention. J Environ Health 67: 30-34

Gettings MA, Kiernan NE (2003) Practices and perceptions of food safety among seniors who prepare meals at home. J Nutr Educ 33: 148-154

Godwin S, Coppings R, Speller-Henderson L, Pearson L (2005) Study finds consumer food safety knowledge lacking. J Family Consum Sci 97: 40-44

Haapala I, Probart C (2004) Food safety knowledge, perceptions, and behaviors among middle school students. J Nutr Educ Behav 36: 71 76

Hair JF, Black WC, Babin BJ, Anderson RE (2010) Multivariate Data Analysis - A global perspective, Pearson Education, INC., Upper Saddle River, New Jersey

Henson S, Traill B (1993) Consumer perceptions of food safety and their impact on food choice. In G. G. Birch \&G. Campbell-Platt (Eds.), Food safety - the challenge ahead (pp. 39-55). Andover: Intercept.

Knabel SJ (1995) Foodborne illness: role of home food handling practices. Food Technol 49: 119-131

Knight PG, Jackson JC, Bain B, Eldemire-Shearer D (2003) Household food safety awareness of selected urban consumers in Jamaica. Int $\mathrm{J}$ Food Sci Nutr 54: 309-320

Li-Cohen AE, Bruhn CM (2002) Safety of consumer handling of fresh produce from the time of purchase to the plate: A comprehensive consumer survey. J Food Prot 65: 1287-1296

Lin TJ (1995) Demographic and socioeconomic influences on the importance of food safety in food shopping. Agric Resour Econ Rev 24: $190-198$

Marušić M, Vranešević T (1997) Istraživanje tržišta, Adeco, Zagreb

Mederios L, Hillers V, Kendall P, Mason A (2001) Evaluation of food safety education for consumers. J Nutr Educ Behav 33: 27-34

Miljkovic D, Nganje W, Ndembe E (2008) Offsetting Behaviour: Consumers' Response. 
Mitakakis TZ, Sinclair MI, Fairley CK, Lightbody PK, Leder K, Hellard ME (2004) Research note: food safety in family homes in Melbourne Australia. J Food Prot 67: 818-822

Nayga RM (1996) Sociodemographic influences on consumers' concern for food safety: The case of irradiation, antibiotics, hormones, and pesticides. Rev Agric Econ 18: 467-475

Radman M (2005) Consumer consumption and perception of organic products in Croatia. Br Food J 107: 263-273

Rimal A, Fletcher SM, McWatters KH, Misra SK, Deodhar S (2001) Perception of food safety and changes in food consumption habits: A consumer analysis. Int J Consum Stud 25: 43-52
Schafer RB, Schafer E, Bultena GL, Hoiberg EO (1993) Food safety: an application of the health belief model. J Nutr Educ 25: 17-23

Tent H (1999) Research on food safety in the 21th Century. Food Control 10: $230-241$

Unklesbay N, Sneed J, Toma R (1998) College students attitudes and knowledge of food safety. J Food Prot 61: 1175-1180

VedovatoI GM, Deborah HMB, Ana MCM, Behrens JH (2014) A scale to evaluate customer attitudes towards food risks in restaurants .Vig Sanit Debate 2: 53-61

WHO (2000) Foodborne disease: A focus for health education. Geneva:WHO 